\title{
Extramedullary Hematopoiesis Simulating Parasagittal Meningioma
}

\author{
R.A. KANDEL, K.P.H. PRITZKER, A.S. GORDON and J.M. BILBAO
}

\begin{abstract}
We report a patient with polycythemia vera and myeloid metaplasia of nine years duration who developed raised intracranial pressure related to a mass obliterating the sagittal fissure. Although clinically and radiologically simulating a meningioma, biopsy revealed extramedullary hematopoiesis involving the falx cerebri. Although uncommon, this case illustrates that myeloproliferative disease can present with symptomatology and radiologic features similar to primary intracranial tumours.
\end{abstract}

RESUMÉ: Nous rapportons l'histoire d'un patient souffrant d'une polycythèmie vraie et de métaplasie myéloïde existant depuis 9 ans et qui développa une augmentation de la pression intracranienne $\dot{a}$ cause d'une masse bloquant la fissure sagitale. Même si cliniquement et radiologiquement la masse simulait un méningiome, la biopsie devait révéler une hématopoièse tumorale extramédullaire impliquant la faulx du cerveau. Même si le fait est rare, le cas présent démontre qu'une maladie myéloproliférative peut imiter les symptômes et les aspects radiologiques des tumeurs intracraniennes primaires.

From: The Departments of Pathology and Medicine, Mount Sinai Hospital and the University of Toronto, Toronto Canada.

Reprint Requests to: Dr. K.P.H. Pritzker, Department of Pathology, Mount Sinai Hospital, 600 University Avenue, Toronto, Canada, M5G 1 X5.

Presented in part at the 43rd Annual Meeting of the Ontario Association of Pathologists, Kingston, Ontario, September 26th, 1980.

\section{INTRODUCTION}

Extramedullary hematopoiesis is a well recognized, although infrequent, complication of such diverse disorders as infection, ( $\mathrm{Hu}$ and Cash, 1930) hemolytic anemia, (Brannon, 1927) or bone marrow replacement by metastatic carcinoma or myeloproliferative disorders. We present in this report a case of a man with a long standing myeloproliferative disorder who developed neurologic symptoms that clinically imitated a midline meningioma.

\section{CASE HISTORY}

A 37 year old man was diagnosed as having polycythemia vera in 1968 . His disease was controlled by intermittent treatment with intravenous $\mathrm{P}^{32}$ and phlebotomies. Nine years after diagnosis, he noted fatigue, epistaxis and easy bruising. Physical examination revealed diffuse petechiae and massive splenomegaly. Laboratory examination showed a hemoglobin of 9.7 $\mathrm{gm} / \mathrm{dl}$ with a leukoerythroblastic blood smear, a WBC of 93,000 cells $/ \mathrm{mm}^{3}$ and a platelet count of 18,000 cells/ $\mathrm{mm}^{3}$. Elective splenectomy for thrombocytopenia revealed extensive myeloid metaplasia histologically. He did well over the next two years but then developed difficulty walking, urinary incontinence and headaches. General physical examination revealed axillary and inguinal lymphadenopathy and hepatomegaly. Neurologic examination showed bilateral papilledema, retinal hemorrhages, diffuse bilateral lower limb spastic paresis which was more marked on the left, left ankle clonus and a left extensor plantar response. Deep quadriceps and Achilles tendon reflexes were symmetrical but exaggerated and bilateral palmomental reflexes could be elicited. Laboratory examination revealed a WBC of $153,0-$ 00 cells $/ \mathrm{mm}^{3}$, hemoglobin of 11.4 $\mathrm{gm} / \mathrm{dl}$ and a platelet count of 37,000 cells $/ \mathrm{mm}^{3}$. A bone marrow biopsy showed hypercellular marrow with a diffuse increase in both myeloid precursors and megakaryocytes. An axillary lymph node biopsy documented the development of widespread extramedullary hematopoiesis. A brain scan disclosed a midline vascular lesion that on cerebral angiography was attached to the inferior edge of the superior sagittal sinus. The CT scan (Fig. 1) showed a large radiodense fusiform lesion involving the falx cerebri. Hemangioblastoma was considered in the differential diagnosis because of its association with polycythemia. However, on the basis of the radiological findings, the clinical diagnosis was meningioma. The lesion was biopsied and hematopoietic tissue consisting of myeloid precursors, mature myeloid cells and megakaryocytes were observed. Two courses of dexamethasone and cranial irradiation were required for alleviation of neurological symptomatology. A repeat CT scan showed minimal shrinkage in tumour size. Over the following year, there was no recurrence of his neurological signs or symptoms but progressive debilitation supervened and he died.

At autopsy, cranial examination revealed a $9 \times 3 \times 3 \mathrm{~cm}$. sausageshaped mass involving the falx cerebri which compressed, but did not infiltrate the adjacent cerebral parenchyma. (Figure 2). Abnormal tissue was also seen in the subdural space of the left posterior fossa and the hypophysis. Histologically, the tissue was identical to that seen at the time of biopsy. (Figure 3) Other major findings included the presence of extramedullary hematopoietic tissue in lymph nodes, liver, spleen, pleura, kidneys and heart.

\section{DISCUSSION}

The dura as well as other potential sites for extramedullary hematopoiesis 


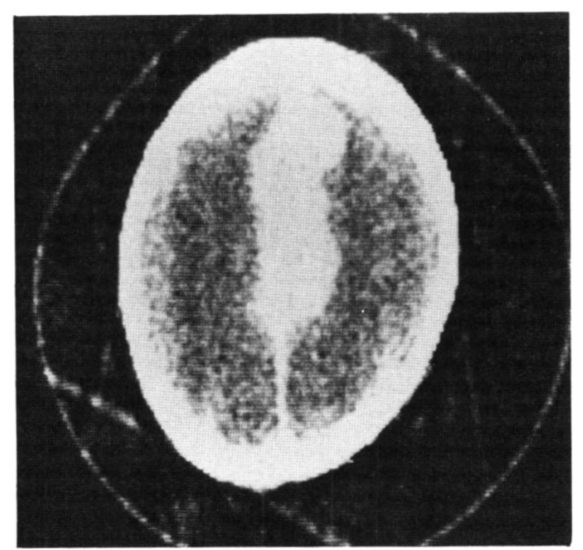

Figure $1-\mathrm{CT}$ scan showing midline mass in falx cerebri. Note radiodensity approximates that of skull.

such as lymph nodes, liver, spleen and perirenal fat are tissues which are hematopoietic in lower vertebrates and in fetal life. (Ward and Block, 1971) Theories postulated to explain the development of this phenomena include: implantation of normal blood element precursors into tissues favourable for their growth, local metaplasia of mesenchymal cells to hematoblasts, and proliferation of a neoplastic stem cell. (Adamson and Fialkow, 1978, Damshek, 1951).

The latter theory is supported by glucose-6-phophate dehydrogenase marker studies which have shown that circulating myeloid cells in both polycythemia vera (Adamson et al, 1976) and myeloid metaplasia (Barr and Fialkow, 1973) contain only one isoenzyme. These findings imply that these tumours arise from a single precursor cell and are neoplastic in origin.

Of 241 reported cases of extramedullary hematopoiesis in a variety of hematologic disorders (AACH, 1971, Brannon, 1927, Glew et al, 1973, $\mathrm{Hu}$ and Cash, 1930, Korpassay and Kelemen, 1949, Lieberman et al, 1965, Ligumski et al, 1978, Polliack and Rosenmann, 1969, Rutman et al, 1972, Vegh and Jankovies, 1964, Ward and Block, 1971) intracranial involvement was found in 18 cases (including the present case) and 8 of these were symptomatic. (Brannon, 1927, Glew et al, 1973, $\mathrm{Hu}$ and Cash, 1930, Korpassay and Kelemen, 1949, Lieberman et al, 1965, Ligumski et al, 1978, Polliack and Rosenmann, 1969, Rutman et al, 1972, Vegh and Jankovies, 1964). Most patients had symptoms related to multifocal dural involvement. The present patient appears unique in that his CNS symptomatology was related to a solitary midline intracranial mass.

Development of intracranial extramedullary hematopoiesis does not appear to be related to either the underlying disease or to the type of therapy received. In the 18 patients, there was almost equal distribution of patients in both treatment or nontreatment groups. Although the case population is small, there does appear to be a predilection for development of symptomatic intracranial extramedullary hematopoiesis in those patients who received some form of therapy. This may be related to the oncogenic potential of the therapeutic agents employed or possibly to the prolonged survival with larger tumour burden in these patients.

In conclusion, symptomatic intracranial extramedullary hematopoiesis is an uncommon finding and may clinically simulate a meningioma. It should be considered in the differential diagnosis of central nervous system lesions in patients with myeloproliferative malignancies. Its occurrence may be related to previous myelosuppresive therapy.

\section{REFERENCES}

CLINICAL PATHOLOGIC CONFERENCE. Myelofibrosis with unusual neurologic abnormalities. AACH Richard Kissane, John (editor) (1971). Am J Med, 51:799-811.

ADAMSON, J.W., FIALKOW, P.J., MURPHY, S., PRCHAL, J.F., STEINMANN, L. (1976) Polycythemia vera: stem cell and probable clonal origin of the disease NEJM, 295:913.

ADAMSON, J.W. and FIALKOW, P.J. (1978). The pathogenesis of myeloproliferative syndromes. $\mathrm{Br} \mathrm{J}$ Hematology, 38:299-303.

BARR, R.D. and FIALKOW, P.J. (1973). Clonal origin of CML. NEJM, 289:307-309.

BRANNON, D. (1927). Extramedullary hematopoiesis in anemias. Bull John Hopkins Hospital, 41:104-136.

DAMSHEK, W. (1951). Some speculations on the myeloproliferative syndromes. Blood, $6: 372-375$

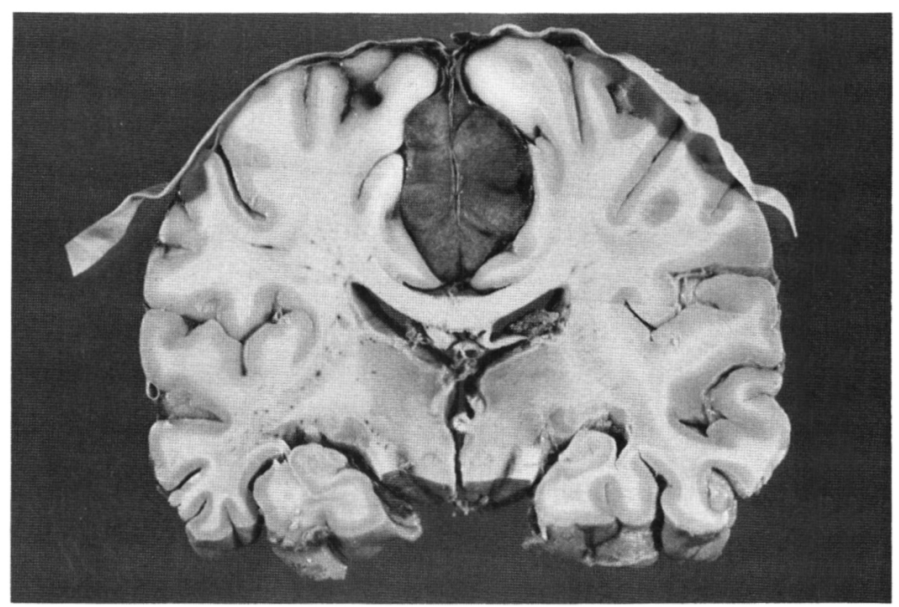

Figure 2 - Coronal section through brain at autopsy. Note that the falx cerebri is preserved in the mass lesion. The mass has compressed the adjacent brain parenchyma.

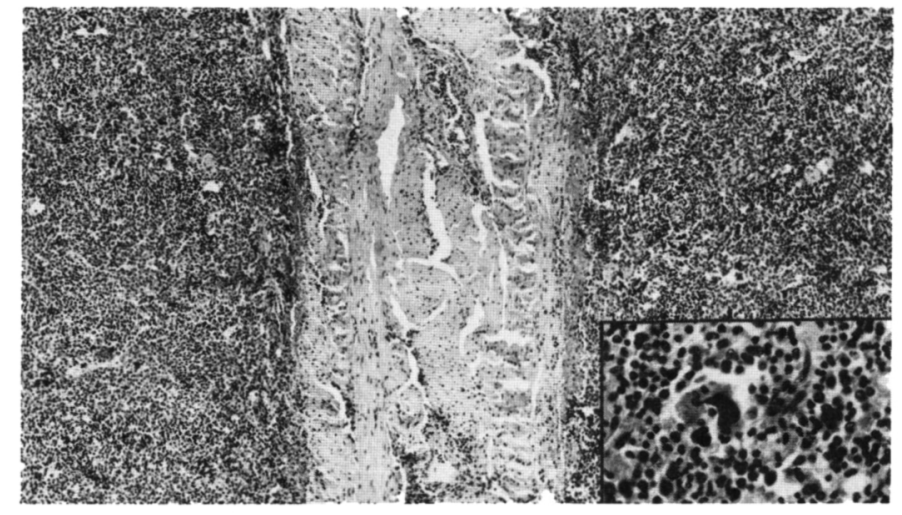

Figure 3 - Photomicrographs of the falx and mass lesion at autopsy. Note the preservation of the fal $x$ with myeloid precursors within blood vessels. The inset shows the cells in the lesion are a mixture of granulocyte precursors, erythrocyte precursors and atypical megakaryocytes. Hematoxylin and Eosin. Magnification X 16. Inset - magnification X 100. 
GLEW, R.H., HAESE, W.H., McINTYRE, P.A. (1973). Myeloid metaplasia with myelofibrosis. The clincial spectrum of EMH and tumour formation. Hopkins Med J, 132:253-270.

HU, C.H. and CASH, J.R. (1930). Erosion of the inner table of the skull by hyperplasia of bone marrow in Kala Azar with extramedullary formation of blood on the surface of the dura. Trans 7th Congress Far East Assoc Trop Med 1927, 3:80-84.

KORPASSAY, B., and KELEMEN, E. (1949). Vaquez-Osler'sche Krankheit-Panmyelose. Acta Hematol, 2:1 10-124.
LIEBERMAN, R.H, ROSVOLL, R.V. LEY, A.B. (1965). Extramedullary myeloid tumours in primary myelofibrosis. Cancer, 18:727-736.

LIGUMSKI, M., POLLIACK, A., BENBASSAT, J. (1978). Myeloid metaplasia of the central nervous system in patients with myelofibrosis and agnogenic myeloid metaplasia. Am J Med Sci, 275:99-103.

POLLIACK, A., and ROSENMANN, E. (1969). Extramedullary hematopoietic tumours of the cranial dura mater. Acta Haematol, 41:43-48.
RUTMAN, J.Y., MEIDINGER, R., KEITH, J.I. (1972). Unusual radiological and neurologic findings in a case of myelofibrosis with EMH. Neurology, 22:567-570.

VEGH, P., and JANKOVIES, R. (1964). Uber Eine Erkrankung an myelosklerosc mit seltenem Verlauf nach Milzent Fernung. Folia Haematologica, 83:16-25.

WARD, H.P., and BLOCK, M.H. (1971). The natural history of $A M M$ and a critical evaluation of its relationship with the myeloproliferative syndrome. Medicine, 50:357-420. 